ISSN 1392-3196 / e-ISSN 2335-8947

Zemdirbyste-Agriculture, vol. 107, No. 4 (2020), p. 359-366

DOI 10.13080/z-a.2020.107.046

\title{
The correlation between the susceptibilities to lambda-cyhalothrin and tau-fluvalinate in Czech and Slovak pollen beetle populations
}

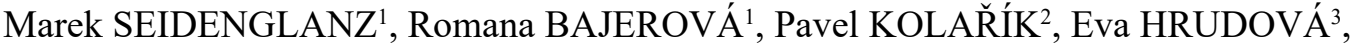 \\ Jiří HAVEL ${ }^{4}$, Ján TÁNCIK ${ }^{5}$, Miriama RUSEŇÁKOVÁ ${ }^{1}$, Peter BOKOR ${ }^{6}$, \\ František KOCOUREK ${ }^{7}$, Jitka STARÁ ${ }^{7}$, Leona VÍCHOVÁ ${ }^{8}$, Jaroslav ŠAFÁ ${ }^{1}$
}

${ }^{1}$ Agritec Plant Research Ltd., Department of Plant Protection

Zemědělská 2520/16, Šumperk 78701, Czech Republic

E-mail: seidenglanz@agritec.cz

${ }^{2}$ Agriculture Research Ltd.

Zahradní 1, Troubsko 66441, Czech Republic

${ }^{3}$ Mendel University in Brno, Faculty of Agronomy

Zemědělská 1, Brno 61300, Czech Republic

${ }^{4}$ OSEVA Development and Research Ltd.

Purkyňova 6, Opava 74601, Czech Republic

${ }^{5}$ ECOPHYTA, s.r.o.

Chrenovská 30, Nitra 94901, Slovakia

${ }^{6}$ Slovak University of Agriculture in Nitra, Faculty of Agrobiology and Food Resources

A. Hlinku 2, Nitra 94976, Slovakia

${ }^{7}$ Crop Research Institute, Department of Integrated Pest Management

Drnovská 507/73, Praha 16106, Czech Republic

${ }^{8}$ Central Institute for Supervising and Testing in Agriculture (ÚKZÚZ),

Department of Diagnostic Laboratories

Šlechtitelů 773/23, Olomouc 77900, Czech Republic

\begin{abstract}
A total of 251 pollen beetle (Brassicogethes aeneus F.) populations sampled in the Czech Republic and Slovakia were tested against both lambda-cyhalothrin and tau-fluvalinate by means of Insecticide Resistance Action Committee (IRAC) susceptibility test method 11, version 03 (glass vial test) over four (2015-2018) years. The results confirmed high levels of resistance to lambda-cyhalothrin in the pollen beetle populations of both countries. Tau-fluvalinate is less affected by resistance, but relatively high proportions of resistant populations at many localities in both countries make this insecticide almost unusable against the pest too. The results of a correlation analysis of lethal concentration ( $\mathrm{LC}$ ) values $\left(\mathrm{LC}_{50}\right.$ and at least partly of $\mathrm{LC}_{90}$ values, too) indicate a moderate level of cross resistance against the two active ingredients in Czech populations. In Slovakian populations, the positive correlation between the $\mathrm{LC}_{50}$ values proved to be significant only in $2018(r=0.66, p<0.001)$.

Despite certain variability in the results of the correlation analysis recorded in this study, the findings indicate another possible decrease in the susceptibility of pollen beetles to pyrethroids, in general, if tau-fluvalinate were used for their control under field conditions.
\end{abstract}

Key words: Brassicogethes aeneus, class I pyrethroids, class II pyrethroids, adult vial test, insecticide resistance, winter oilseed rape.

Please use the following format when citing the article:

Seidenglanz M., Bajerová R., Kolař́ík P., Hrudová E., Havel J., Táncik J., Ruseňáková M., Bokor P., Kocourek F., Stará J., Víchová L., Šafáŕ J. 2020. The correlation between the susceptibilities to lambda-cyhalothrin and tau-fluvalinate in Czech and Slovak pollen beetle populations. Zemdirbyste-Agriculture, 107 (4): 359-366. DOI 10.13080/z-a.2020.107.046 


\section{Introduction}

The pollen beetle (Brassicogethes aeneus F.) is one of the most important insect pests in oilseed rape crops in Europe during springtime. Adults may damage any of the flowering structures during the green to yellow bud stages. Feeding damage causes oilseed rape flower bud abscission, often leading to extensive yield losses that can approach $80 \%$ (Hansen, 2004).

At present, pyrethroid-resistant populations are most prevalent in Western, Central and North Europe and are becoming established in the East (Slater et al., 2011; Kaiser et al., 2018). The development of resistance and the progressive spread of pollen beetle populations resistant to pyrethroids (especially to class II pyrethroids) through the various countries and regions of Europe have been described and documented in many papers: Derron et al. (2004), Thieme et al. (2008), Tiilikainen and Hokkanen (2008), Wegorek et al. (2009), Philippou et al. (2011), Zimmer and Nauen (2011 a) and Heimbach and Müller (2013). Seidenglanz et al. (2015 a; b; 2017) and Stará and Kocourek (2018) documented the spread of resistant populations in the Czech Republic (CZ) and also partly in Slovakia (SK) from 2009.

Currently, the insecticides recommended for the control of resistant pollen beetles in oilseed rape crops, which are considered to be suitable for usage in an antiresistance strategy, especially pymetrozine, indoxacarb, class I pyrethroid etofenprox, organophosphates and spinosad in some countries, show (with the exception of spinosad) high toxicity to bees. So, these insecticides are not fully adequate alternatives to class II pyrethroids, because, in general, class II pyrethroids show somewhat lower toxicity to bees, especially in the cases, when the recommended field rates do not exceed $10 \mathrm{~g} \mathrm{ha}^{-1}$ a.i. (ÚKZÚZ, http://eagri.cz/public/web/en/ukzuz/portal/).

Another disadvantage of the two important active ingredients, pymetrozine and indoxacarb, as insecticides recommended for pollen beetle control, is their relatively low efficacy against oilseed rape and cabbage stem weevils (Ceutorhynchus napi and C. pallidactylus) (Seidenglanz et al., 2018). Growers should deal with the complication contingency in those European regions, where the stem weevils are important insect pests for oilseed rape. One insecticide application, which is usually the first spring spray in many European regions, is not enough to control the insect pests (Rubil et al., 2018). Especially this is true for C. pallidactylus females that frequently show lengthy egg-laying periods (Junk et al., 2012; Seidenglanz et al., 2018), and so even the second spring application (primarily perceived by farmers as a treatment against pollen beetles) is important to prevent stem damage induced by their larvae and, in conjunction with this, the detrimental effect of some fungal pathogens, especially Phoma lingam, Alternaria spp. and Botrytis cinerea (Broschewitz et al., 1993; Krause et al., 2006).

Another important group of insecticides, neonicotinoids (thiacloprid and acetamiprid), with a somewhat lower toxicity to bees (ÚKZÚUZ, http:// eagri.cz/public/web/en/ukzuz/portal/), is also under threat of resistance. Although some studies deny this possibility (Zimmer, Nauen, 2011 a; Heimbach, Müller, 2013), significant shifts in pollen beetle susceptibility to thiacloprid have been reported in Europe recently (Kaiser et al., 2018; Rubil et al., 2018). Furthermore, these insecticides are needed for sprays targeted at pod midges (Dasineura brassicae) and seed pod weevils (Ceutorhynchus obstrictus), which usually follow the applications aimed at pollen beetles. Neonicotinoids are markedly more effective against pod midges than pyrethroids under field conditions, and farmers prefer them for the application. The usage of neonicotinoids against pollen beetles would create a condition for two applications of them in sequence. Thus, even the neonicotinoids are not fully adequate alternatives for class II pyrethroids.

Although the crop would usually be sprayed against the pollen beetles before flowering, under normal field conditions growers in relatively frequent cases need an insecticide, which can also be used at the flowering stage but has only low detrimental effects against beneficial organisms and, particularly in the case of oilseed rape, honey bees. For such applications, the active ingredient tau-fluvalinate should be very suitable due to its low toxicity to bees (Jackowski et al., 2008; SanchezBayo, Goka, 2014) and hymenopteran parasitoids of oilseed rape insect pests (Jansen, Gomez, 2014). Taufluvalinate, a member of a group of class I pyrethroids, has been used for a long time in the control of varroa mite (Varroa jacobsoni). In all commercially used forms it has been merely claimed as tolerated by honey bees though never as entirely harmless to them (Mozes-Koch et al., 2000; Tsigouri et al., 2004).

In the situation, which European growers are confronted with, it is necessary to know if the pollen beetles have sustained susceptibility to tau-fluvalinate and whether there is any relationship between the resistance of pollen beetles to class II pyrethroids and possible changes in susceptibility to the active ingredient. Some studies (Hansen, 2003; 2008; Wegorek et al., 2009; Moores et al., 2011; Nauen et al., 2012) demonstrate a decrease in the pollen beetle's susceptibility to taufluvalinate in European countries and, therefore, they do not recommend usage of the insecticide for pollen beetle control. On the other hand, some studies show that the levels of susceptibility to this active ingredient are not so low (and remain relatively stable) even in regions, where class II pyrethroids have already become completely ineffective (Šmatas et al., 2012; Brandes, Heimbach, 2018; Brandes et al., 2018) and exclude (or did not confirm) cross-resistance between class II pyrethroids (mostly represented by lambda-cyhalothrin or deltamethrin in laboratory tests) and tau-fluvalinate (Stará, Kocourek, 2018).

The aim of this study was to answer the question, whether the use of tau-fluvalinate is an acceptable option for pollen beetle control in the regions, where most of the insect pest populations have shown high levels of resistance to common esteric (in general, class II) pyrethroids such as lambda-cyhalothrin, deltamethrin, cypermethrin, alphacypermethrin, zeta-cypermethrin, etc.

\section{Materials and methods}

Pollen beetle (Brassicogethes aeneus) 56 populations were tested against pyrethroids lambdacyhalothrin and tau-fluvalinate in 2015. In the course of the following three years, a total of 63 (2016), 61 (2017) and 71 (2018) B. aeneus populations were tested. Some of the populations were sampled in the western part of the Czech Republic (CZ, Bohemia, BO), some in the eastern 
part of CZ (Moravia, MO) and some also in Slovakia (SK) (Table 1).

Table 1. The numbers of Brassicogethes aeneus populations tested against pyrethroids lambdacyhalothrin and tau-fluvalinate ( $=$ the numbers of pairs for correlation analysis) in 2015-2018

\begin{tabular}{ccccc}
\hline \multirow{2}{*}{ Year } & \multicolumn{4}{c}{ The numbers of tested pairs } \\
\cline { 2 - 5 } & $\begin{array}{c}\text { Czechia and } \\
\text { Slovakia }\end{array}$ & Bohemia $^{1}$ & Moravia $^{1}$ & Slovakia \\
\hline 2015 & 56 & 11 & 35 & 10 \\
2016 & 63 & 16 & 26 & 21 \\
2017 & 61 & 16 & 24 & 21 \\
2018 & 71 & 28 & 27 & 16 \\
\hline
\end{tabular}

Note. ${ }^{1}$ - Bohemia is the western part, and Moravia is the eastern part of Czech Republic.

For testing purposes, glass vial test recommended by Insecticide Resistance Action Committee (IRAC, https://irac-online.org/methods/) were used. For testing of $B$. aeneus susceptibility to lambda-cyhalothrin and tau-fluvalinate, IRAC susceptibility test method No. 011, version 3 was used. Unlike the IRAC methodology, additional (the highest) concentration was used in our tests with lambda-cyhalothrin. Were tested the following concentrations: $0.3,1.5$ and $7.5 \mathrm{~g} \mathrm{ha}^{-1}$ a. i. (recommended field rate in Europe) (Zimmer, Nauen, 2011 a); 37.5 and $112.5 \mathrm{~g} \mathrm{ha}^{-1}$ a.i. and untreated control. For tau-fluvalinate, were tested the following concentrations: 1.92, 9.6 and $48 \mathrm{~g} \mathrm{ha}^{-1}$ a.i. (recommended field rate in Europe) (Zimmer, Nauen, 2011 b); $240 \mathrm{~g} \mathrm{ha}^{-1}$ a.i. and untreated control. For each population three replicates were used for each tested concentration.

Ten adult pollen beetles were placed in each vial. The vials with beetles were stored in constant environment facilities at $18 \pm 2{ }^{\circ} \mathrm{C}$ temperature and 16/8 h light/dark. After $24 \mathrm{~h}$ the beetles were tipped out of the vials and scored on filter discs. Insects incapable of coordinated movement in the course of $1 \mathrm{~min}$, even after gentle stimulation with tweezers, were scored as dead for establishing the pyrethroid resistance indices (= classification codes $1-5$ ) for individual populations. One of the five codes for both active ingredients was assigned to each population according to recorded mortality induced by the recommended field rate: lambdacyhalothrin $7.5 \mathrm{~g} \mathrm{ha}^{-1}$ a.i., tau-fluvalinate $48 \mathrm{~g} \mathrm{ha}^{-1}$ a.i., and a five-times lower rate: lambda-cyhalothrin $1.5 \mathrm{~g} \mathrm{ha}^{-1}$ a.i., tau-fluvalinate $9.6 \mathrm{~g} \mathrm{ha}^{-1}$ a.i.

Code 1 = highly susceptible population: mean percentage of mortality induced by 7.5 and $1.5 \mathrm{~g} \mathrm{ha}^{-1}$ of lambda-cyhalothrin (or 48 and $9.6 \mathrm{~g} \mathrm{ha}^{-1}$ a.i. for taufluvalinate) is $100 \%$; Code 2 = susceptible population: mean percentage mortality induced by $7.5 \mathrm{~g} \mathrm{ha}^{-1}$ of lambda-cyhalothrin (or $48 \mathrm{~g} \mathrm{ha}^{-1}$ a.i. for tau-fluvalinate) is $100 \%$, mean percentage of mortality induced by $1.5 \mathrm{~g} \mathrm{~h} \mathrm{a}^{-1}$ of lambda-cyhalothrin (or $9.6 \mathrm{~g} \mathrm{ha}^{-1}$ a.i. for taufluvalinate) is lower than $100 \%$; Code $3=$ moderately resistant population: mean percentage of mortality induced by $7.5 \mathrm{~g} \mathrm{ha}^{-1}$ of lambda-cyhalothrin (or $48 \mathrm{~g} \mathrm{ha}^{-1}$ a.i. for tau-fluvalinate) is between $90-99.99 \%$; Code 4 $=$ resistant population: mean percentage of mortality induced by $7.5 \mathrm{~g} \mathrm{ha}^{-1}$ of lambda-cyhalothrin (or $48 \mathrm{~g} \mathrm{ha}^{-1}$ a.i. for tau-fluvalinate) is between $50-89.99 \%$; Code $5=$ highly resistant population: mean percentage of mortality induced by $7.5 \mathrm{~g} \mathrm{ha}^{-1}$ of lambda-cyhalothrin (or $48 \mathrm{~g} \mathrm{ha}^{-1}$ a.i. for tau-fluvalinate) is below $50 \%$ according to Abbott's (1925) formula.

For each population the values of lethal concentration (LC) required to kill 50\% $\left(\mathrm{LC}_{50}\right)$ and $90 \%\left(\mathrm{LC}_{90}\right)$ of the population were also estimated for the two active ingredients (expressed in $\mathrm{g} \mathrm{ha}^{-1}$ a.i.); length of exposure $-24 \mathrm{~h}$. For the calculations of probit regression, Polo Plus, version 2.0 (LeOra Software LLC, USA) was used. This resulted in 56, 63, 61 and 71 pairs of simultaneously related LC values for correlation analysis in 2015, 2016, 2017 and 2018 for all CZ and SK populations tested (Table 1). Correlation analyses were made with both non-transformed and $\log 10$ transformed $\mathrm{LC}$ values. The reason for $\log$ transformation of $\mathrm{LC}$ values was to achieve a normal distribution of the data in the individual collections of LC values. Pearson's correlation coefficients were determined (for confirmation of statistical significance two values of $p$ were used: $p<0.05$ or 0.001 ) for the related pairs of LC values (lambdacyhalothrin $\mathrm{LC}_{50,90} \times$ tau-fluvalinate $\left.\mathrm{LC}_{50,90}\right)$. Calculations were made using software Statistica, version 12 (StatSoft Inc., USA).

Lambda-cyhalothrin (analytical standard; batch number HUD6A 3514) was obtained from Syngenta Czech Ltd., and tau-fluvalinate (analytical standard; batch number 102851-06-9) - from Sigma-Aldrich.

\section{Results}

In general, $\mathrm{CZ}$ and $\mathrm{SK}$ pollen beetle populations showed high levels of resistance to lambda-cyhalothrin. The frequencies of highly resistant and resistant populations were lower in SK than in $\mathrm{CZ}$ over the four (2015-2018) years. Contrary to the situation in CZ, the proportions of susceptible populations were not so negligible in SK during the experimental period. Some populations sampled in the eastern part of SK still showed a high susceptibility to lambda-cyhalothrin. Such populations were more frequent in SK collections sampled in 2016. According to IRAC classification, the majority of populations (especially in CZ) were scored as resistant or highly resistant during the period (Table 2).

The variability in $\mathrm{LC}_{50}$ values estimated for the individual populations was relatively high in $\mathrm{CZ}$ and even SK collections (Fig. 1).

In comparison with the results of lambdacyhalothrin testing, there were markedly higher frequencies of populations susceptible to tau-fluvalinate (according to IRAC classification) in the annual collections in both countries (Table 3 ). On the other hand, the proportions of resistant populations were not negligible either, especially in CZ. As with lambdacyhalothrin, the situation was worse in $\mathrm{CZ}$ than in SK, which is located more to the east.

The variability in the levels of $\mathrm{LC}_{50}$ and $\mathrm{LC}_{90}$ values estimated for the individual populations was relatively high in the pollen beetle collections, even in the case of this active ingredient. MO populations showed a somewhat higher variability than SK populations (Fig. 2).

Relatively high variabilities in the levels of $\mathrm{LC}_{50}$ and $\mathrm{LC}_{90}$ values recorded in the annual pollen beetle collections for both active ingredients provided 
Table 2. Classification of Czech Republic (CZ) and Slovakia (SK) Brassicogethes aeneus populations' susceptibility $v s$ resistance to lambda-cyhalothrin assigned according to IRAC susceptibility test method No. 011, version 3

\begin{tabular}{cccccc}
\hline \multirow{2}{*}{$\begin{array}{c}\text { Year, } \\
\text { country }\end{array}$} & \multicolumn{5}{c}{ Proportions (\%) of populations with classification codes (1-5) vs resistance indices } \\
\cline { 2 - 5 } & 1 & 2 & 3 & 4 & 5 \\
\hline $2015, \mathrm{CZ}$ & 0.00 & 0.00 & 3.57 & 41.07 & 55.36 \\
$2016, \mathrm{CZ}$ & 0.00 & 5.36 & 0.00 & 50.00 & 44.64 \\
$2017, \mathrm{CZ}$ & 0.00 & 0.00 & 0.00 & 49.02 & 50.98 \\
$2018, \mathrm{CZ}$ & 0.00 & 0.00 & 1.56 & 39.06 & 59.38 \\
$2015, \mathrm{SK}$ & 0.00 & 19.05 & 18.18 & 57.82 & 0.00 \\
$2016, \mathrm{SK}$ & 4.76 & 4.76 & 4.76 & 47.62 & 42.86 \\
$2017, \mathrm{SK}$ & 0.00 & 11.76 & 0.00 & 64.71 & 23.53 \\
\hline
\end{tabular}

Note. In this table, the results for $\mathrm{CZ}$ are not divided into western (Bohemia) and eastern (Moravia) parts.

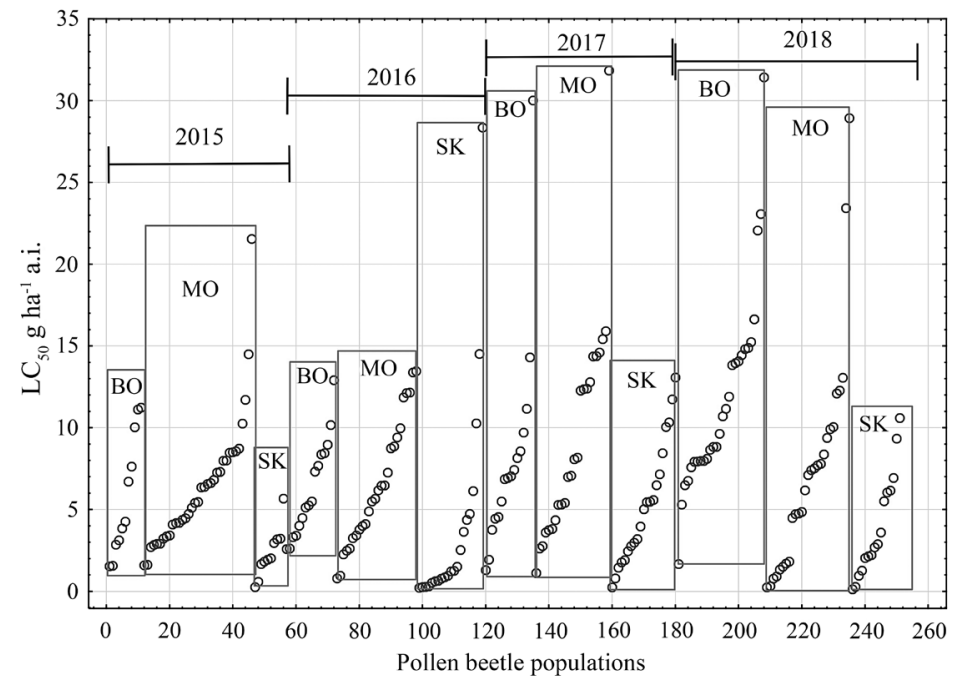

BO - Bohemia, MO - Moravia, SK - Slovakia

Figure 1. Distribution of lambda-cyhalothrin $\mathrm{LC}_{50}$ values in the annual collections of pollen beetles gathered from the three different regions in 2015-2018

Table 3. Classification of Czech Republic (CZ) and Slovakia (SK) Brassicogethes aeneus populations' susceptibility $v s$ resistance to tau-fluvalinate assigned according to IRAC susceptibility test method No. 011, version 3

\begin{tabular}{cccccc}
\hline Year, & \multicolumn{5}{c}{ Proportions (\%) of populations with classification codes $(1-5) v s$ resistance indices } \\
\cline { 2 - 5 } country & 1 & 2 & 3 & 4 & 5 \\
\hline $2015, \mathrm{CZ}$ & 0.00 & 34.04 & 17.02 & 46.81 & 2.13 \\
$2016, \mathrm{CZ}$ & 0.00 & 53.34 & 33.33 & 13.33 & 0.00 \\
$2017, \mathrm{CZ}$ & 7.50 & 42.50 & 32.50 & 17.50 & 0.00 \\
$2018, \mathrm{CZ}$ & 0.00 & 43.11 & 17.24 & 34.48 & 5.17 \\
$2015, \mathrm{SK}$ & 0.00 & 30.00 & 70.00 & 0.00 & 0.00 \\
$2016, \mathrm{SK}$ & 9.25 & 61.90 & 14.29 & 14.29 & 0.00 \\
$2017, \mathrm{SK}$ & 4.76 & 42.86 & 42.86 & 9.52 & 0.00 \\
$2018, \mathrm{SK}$ & 6.25 & 62.50 & 25.00 & 6.25 & 0.00 \\
\hline
\end{tabular}

Note. In this table, the results for $\mathrm{CZ}$ are not divided into western (Bohemia) and eastern (Moravia) parts.

the prerequisite for a successful correlation analysis. Significant positive correlations between $\mathrm{LC}_{50}$ values estimated for lambda-cyhalothrin and tau-fluvalinate were recorded, especially in MO and BO populations sampled in 2015, 2016 and 2018. In SK collections, a significant positive correlation between $\mathrm{LC}_{50}$ values was recorded only in 2018. Positive correlations between $\log 10$ transformed $\mathrm{LC}_{50}$ values were significant in all cases (in $\mathrm{MO}, \mathrm{BO}$ and SK collections) in 2016 and 2018. In MO collections, significant positive correlations between $\mathrm{LC}_{90}$ values (untransformed and $\log$ transformed) were recorded in three $(2015,2016$ and 2018) seasons. Contrary to that, a significant correlation between the $\mathrm{LC}_{90}$ values in the $\mathrm{SK}$ populations was recorded only in 2016 (and only in the case of $\log 10$ transformed $\mathrm{LC}_{90}$ values). Correlations between $\log \mathrm{LC}_{90}$ values determined for the overall $\mathrm{CZ}$ and $\mathrm{SK}$ collections proved to be positive and significant in each of the four seasons (Table 4). 


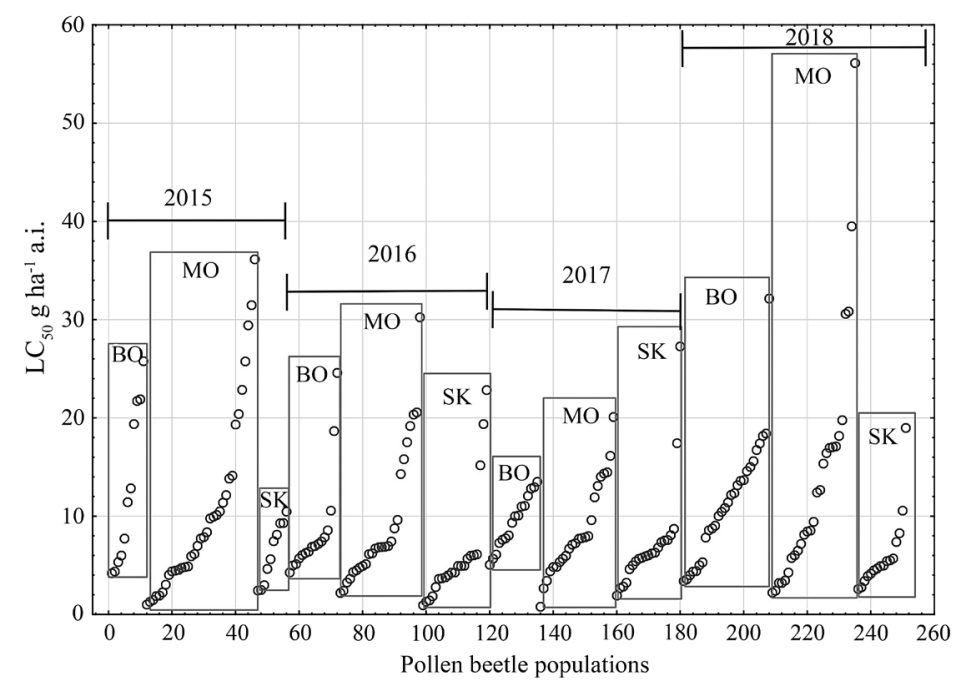

BO - Bohemia, MO - Moravia, SK - Slovakia

Figure 2. Distribution of tau-fluvalinate $\mathrm{LC}_{50}$ values in the annual collections of pollen beetles gathered from the three different regions in 2015-2018

Table 4. Results of a correlation analysis between lethal concentration (LC) values estimated for the two active ingredients lambda-cyhalothrin $v$ s tau-fluvalinate when compared simultaneously

\begin{tabular}{|c|c|c|c|c|c|}
\hline \multirow{2}{*}{$\begin{array}{c}\text { Year, } \\
\text { country / region }\end{array}$} & \multirow{2}{*}{$\begin{array}{c}\text { Number of } \\
\text { populations } \\
\text { analysed }\end{array}$} & \multicolumn{4}{|c|}{ Pearson's correlation coefficients and $P$ values for: } \\
\hline & & $\begin{array}{c}\mathrm{LC}_{50} \\
\text { values }\end{array}$ & $\begin{array}{c}\log \mathrm{LC}_{50} \\
\text { values }\end{array}$ & $\begin{array}{c}\mathrm{LC}_{90} \\
\text { values }\end{array}$ & $\begin{array}{c}\log \mathrm{LC}_{90} \\
\text { values }\end{array}$ \\
\hline 2015, CZ and SK & 56 & $\mathbf{0 . 4 3}(p<0.05)$ & $\mathbf{0 . 3 9}(p<0.05)$ & $0.41(p<0.05)$ & $0.46(p<0.001)$ \\
\hline 2015, CZ, Bohemia & 11 & $0.63(p<0.05)$ & $0.55(p>0.05)$ & $0.25(p>0.05)$ & $0.25(p>0.05)$ \\
\hline 2015, CZ, Moravia & 35 & $0.34(p<0.05)$ & $0.38(p<0.05)$ & $0.47(p<0.001)$ & $0.56(p<0.001)$ \\
\hline 2015, SK & 10 & $0.43(p>0.05)$ & $0.44(p>0.05)$ & $-0.23(p>0.05)$ & $-0.19(p>0.05)$ \\
\hline 2016, CZ and SK & 63 & $0.45(p<0.001)$ & $0.67(p<0.001)$ & $0.17(p>0.05)$ & $0.51(p<0.001)$ \\
\hline 2016, CZ, Bohemia & 16 & $0.67(p<0.05)$ & $0.56(p<0.05)$ & $-0.23(p>0.05)$ & $-0.17(p>0.05)$ \\
\hline 2016, CZ, Moravia & 26 & $0.72(p<0.001)$ & $\mathbf{0 . 5 8}(p<0.001)$ & $0.71(p<0.001)$ & $0.65(p<0.001)$ \\
\hline 2016, SK & 21 & $0.15(p>0.05)$ & $0.65(p<0.001)$ & $0.03(p>0.05)$ & $0.48(p<0.05)$ \\
\hline 2017, CZ and SK & 61 & $-0.03(p>0.05)$ & $0.13(p>0.05)$ & $0.23(p>0.05)$ & $0.27(p<0.05)$ \\
\hline 2017, CZ, Bohemia & 16 & $0.34(p>0.05)$ & $0.43(p>0.05)$ & $0.51(p<0.05)$ & $0.44(p>0.05)$ \\
\hline 2017, CZ, Moravia & 24 & $-0.13(p>0.05)$ & $-0.15(p>0.05)$ & $0.04(p>0.05)$ & $0.33(p>0.05)$ \\
\hline 2017, SK & 21 & $0.18(p>0.05)$ & $0.33(p>0.05)$ & $-0.18(p>0.05)$ & $-0.15(p>0.05)$ \\
\hline 2018, CZ and SK & 71 & $\mathbf{0 . 6 0}(p<0.001)$ & $\mathbf{0 . 3 8}(p<0.001)$ & $\mathbf{0 . 6 0}(p<0.001)$ & $0.54(p<0.001)$ \\
\hline 2018, CZ, Bohemia & 28 & $\mathbf{0 . 6 3}(p<0.001)$ & $0.54(p<0.001)$ & $0.40(p<0.05)$ & $0.39(p<0.05)$ \\
\hline 2018, CZ, Moravia & 27 & $\mathbf{0 . 6 7}(p<0.001)$ & $0.39(p<0.05)$ & $0.62(p<0.001)$ & $0.62(p<0.001)$ \\
\hline 2018, SK & 16 & $0.66(p<0.001)$ & $0.65(p<0.05)$ & $-0.07(p>0.05)$ & $0.08(p>0.05)$ \\
\hline
\end{tabular}

Note. Bold values indicate the cases, where a significant positive correlation $(p<0.05$ or $p<0.001)$ was recorded between the analysed LC values; log transformation of the LC values estimated for both active ingredients was made before the analysis.

\section{Discussion}

The results confirmed high levels of resistance to pyrethroids from class II in both $\mathrm{CZ}$ and SK pollen beetle populations. This agrees with many studies describing the situation in Europe (Zimmer, Nauen, 2011 a; Heimbach, Müller, 2013; Kaiser et al., 2018). The results also indicate some trend in decreasing proportions of resistant populations (and $\mathrm{LC}_{50}$ values) in an easterly direction. This has already been recorded in previous monitoring activities covering large parts of Europe (Zimmer, Nauen, 2011 a).

Tau-fluvalinate was shown to be less affected by resistance than lambda-cyhalothrin. However, the proportions of resistant populations (and highly resistant populations in some years) make the insecticide almost unusable against pollen beetles in many localities in $\mathrm{CZ}$ and to some extent also in SK. The fact that some pyrethroids (besides tau-fluvalinate also bifenthrin and etofenprox) were shown to be less affected by resistance has already been mentioned in some stu dies (Zimmer, Nauen, 2011 a; b; Heimbach, Müller, 2013; Zimmer et al., 2014; Rubil et al., 2018). The situation in SK is better than in $\mathrm{CZ}$, the decrease in the proportions of resistant populations (and $\mathrm{LC}_{50}$ values) from west to east seems to be confirmed for this active ingredient also.

When the somewhat debatable season of 2017, in which MO populations in particular behaved differently, was eliminated, in all three other cases (2015, 
2016 and 2018) the correlation coefficients based on $\mathrm{LC}_{50}$ values calculated for the overall $\mathrm{CZ}$ and $\mathrm{SK}$ collections ranged from 0.43 to 0.60 (mean 0.49 ), and the positive correlations were statistically significant. Very similar results were also obtained with $\log$ transformed $\mathrm{LC}_{50}$ values for the three seasons. So, although the season 2017 substantially differed from the other seasons, in general, the results of the correlation analysis of $\mathrm{LC}_{50}$ values (and at least partly of $\mathrm{LC}_{90}$ values too) indicate a moderate level of cross resistance between lambda-cyhalothrin and tau-fluvalinate in $\mathrm{CZ}$ and SK pollen beetle populations assessed as one group. Cross resistance to tau-fluvalinate in pollen beetles has already been documented at a moderate level for Denmark (Hansen, 2008) and Sweden (Kudsk, 2010). Zimmer and Nauen (2011 b) also documented moderate levels of cross resistance between lambda-cyhalothrin and tau-fluvalinate $(r=0.509, p=$ 0.0068 ) in a group of 27 differently resistant populations sampled in several European countries (Germany, France, United Kingdom, Poland, Czech Republic, Sweden, Finland and Ukraine) in 2010.

Why did the MO populations (and somewhat less apparently also the BO populations) behave differently in 2017? Further factors could have influenced the results. In 2017, very low abundances of pollen beetles occurred in crops in CZ. This could be related to the negative effect of an unusually warm winter 2016-2017 on mortality during adult hibernation. So, in that season we worked with pre-selected populations to some extent.

From the graph illustrating distributions of tau-fluvalinate $\mathrm{LC}_{50}$ values in the regional pollen beetle collections for the four years, it is apparent that the values of $\mathrm{LC}_{50}$ in both $\mathrm{MO}$ and $\mathrm{BO}$ populations were markedly less variable (fewer populations with very high $\mathrm{LC}_{50}$ values were present in the collections) in 2017 than in the other three seasons (Fig. 2). Contrary to tau-fluvalinate, for lambda-cyhalothrin, such a trend was not recorded (Fig. 1). This may indicate that the individuals with high resistance to tau-fluvalinate suffered from higher mortality during overwintering and so their frequencies decreased in MO and BO populations after the warm winter. As documented in many other insect species, there can be fitness costs associated with resistance (Gazave et al., 2001; Kliot, Ghanim, 2012).

All-important findings strongly suggest that pyrethroid (cross-) resistance in pollen beetle is based on oxidative degradation by cytochrome P450 (Zimmer, Nauen, 2011 b; Zimmer et al., 2014), but the specific enzyme(s) involved has (have) not been identified. According to Zimmer et al. (2014), the P450 enzyme CYP6BQ23 especially could be correlated with high levels of pyrethroid resistance in pollen beetles. Despite this finding, the authors cannot exclude the possibility that other CYP6BQ enzymes are overexpressed in resistant strains in addition to CYP6BQ23. Different enzymes could show somewhat different substrate specificity to lambda-cyhalothrin or tau-fluvalinate. Hypothetically, the warm winter could influence the population's composition and through that the levels of expressions of different cytochrome P450 in them. This could be the reason why the results of the correlation analysis calculated for MO and BO populations in 2017 differed so markedly from the other three seasons.
And why did the more easterly located SK populations show markedly lower levels of correlations between lambda-cyhalothrin and tau-fluvalinate $\mathrm{LC}_{50}$ values in the first three years of the study? Some indication that the relationship between susceptibilities to lambda-cyhalothrin and tau-fluvalinate could change in pollen beetle populations inhabiting one region over the course of time may be drawn from the comparison of the results of this study with those reported by Stará and Kocourek (2018). They assessed the susceptibility of nine pollen beetle populations, which were repeatedly sampled in central Bohemia (= BO) over seven (20092015) years, against lambda-cyhalothrin, etofenprox and tau-fluvalinate, and did not record any positive correlation ( $r=-0.087, p=0.553$; non-significant, respectively) between $\mathrm{LC}_{50}$ values determined for lambda-cyhalothrin and tau-fluvalinate in the populations analysed for the whole experimental period as one group.

However, the results of this study demonstrate positive correlations between the $\mathrm{LC}_{50}$ values in the $\mathrm{BO}$ populations sampled somewhat later. The comparison may indicate that in SK populations a similar change happened as in the BO populations. But it occurred with some delay. So, hypothetically in SK populations the cytochrome P450 composition could have changed continuously during the four years, and these changes are reflected in the results of correlation analysis.

\section{Conclusions}

1. In the course of 2015 to 2018 , the proportions of pollen beetle populations resistant to tau-fluvalinate were relatively high, especially in Czech Republic (17.50$48.94 \%$ of resistant populations), while the proportions of resistant pollen beetle populations in Slovakia were lower (6.25-14.29\% of resistant populations).

2. Despite certain variability in the results of the correlation analysis recorded in this study, the findings indicate a moderate level of cross resistance between lambda-cyhalothrin and tau-fluvalinate in Czech Republic and Slovakia pollen beetle populations assessed as one group.

3. If tau-fluvalinate was widely used for control of pollen beetles under field conditions, the resistance to pyrethroids in general could increase.

4. Although the pollen beetles are less resistant to tau-fluvalinate than to lambda-cyhalothrin, it is not an acceptable option for pollen beetle control in the regions, where most of the insect pest populations have shown high levels of resistance to common esteric (in general, class II) pyrethroids.

\section{Acknowledgements}

Supported by the National Agency of Agricultural Research (Ministry of Agriculture of the Czech Republic) under Grants QK1820081 and QJ1610217. In the course of manuscript preparation Grant MZE-RO1018 (Ministry of Agriculture of the Czech Republic) was also used.

The authors also thank Eoghan O'Reilly for revision of the manuscript.

Received 19122019 Accepted 16082020 


\section{References}

1. Abbott W. S. 1925. A method of computing the effectiveness of an insecticide. Journal of Economic Entomology, 18: 265-267. https://doi.org/10.1093/jee/18.2.265a

2. Brandes M., Heimbach U. 2018. Pyrethroid resistance of insect pests of oilseed rape in Germany. IOBC/WPRS Bulletin, 136: 69-72.

3. Brandes M., Heimbach U., Ulber B. 2018. Impact of insecticides on oilseed rape bud infestation with eggs and larvae of pollen beetle (Brassicogethes aeneus (Fabricius)). Arthropod-Plant Interactions, 12: 811-821. https://doi.org/10.1007/s11829-018-9616-y

4. Broschewitz B., Steinbach P., Goltermann S. 1993. Einfluss stengelbewohnender tierischer Schaderreger auf den Befall von Winterraps mit Phoma lingam und Botrytis cinerea. Gesunde Pflanzen, 45 (3): 106-110 (in German).

5. Derron J. O., Le Clech E., Bezencon N., Goy G. 2004. Résistance des méligethes du colza auxpyréthrinoides dans les bassin lémenique. Revue Suisse Agriculture, 36: 237-242 (in French).

6. Gazave É., Chevillon C., Lenormand T., Marquine M., Raymond M. 2001. Dissecting the cost of insecticide resistance genes during the overwintering period of the mosquito Culex pipiens. Heredity, 87: 441-448. https://doi.org/10.1046/j.1365-2540.2001.00926.x

7. Hansen L. M. 2003. Insecticide-resistant pollen beetles (Meligethes aeneus F.) found in Danish oilseed rape (Brassica napus L.) fields. Pest Management Science, 59: 1057-1059. https://doi.org/10.1002/ps.737

8. Hansen L. M. 2004. Economic damage threshold for pollen beetles (Meligethes aeneus $\mathrm{F}$.) in spring oilseed rape (Brassica napus L.) crops. Crop Protection, 23: 43-46. https://doi.org/10.1016/S0261-2194(03)00167-4

9. Hansen L. M. 2008. Occurrence of insecticide resistant pollen beetles (Meligethes aeneus F.) in Danish oilseed rape (Brassica napus L.) crops. Bulletin OEPP/EPPO Bulletin, 38: 95-98. https://doi.org/10.1111/j.1365-2338.2008.01189.x

10. Heimbach U., Müller A. 2013. Incidence of pyrethroidresistant oilseed rape pests in Germany. Pest Management Science, 69 (2): 209-216. https://doi.org/10.1002/ps.3351

11. Jackowski J., Klukowski Z., Irzykowicz M. 2008. The effect of $\tau$-fluvalinate and $\lambda$-cyhalothrin on two parasitic species of Phradis spp. (Hymenoptera, Ichneumonidae, Tersilochinae). Pestycydy/Pesticides, (3-4): 79-92.

12. Jansen J.-P., Gomez G. S. M. Y. 2014. A large field trial to assess the short-term and long-term effects of 4 insecticides used to control the pollen beetle on parasitic hymenoptera in oilseed rape. Integrated Control in Oilseed Crops IOBCWPRS Bulletin, 104: 67-74.

13. Junk J., Eickermann M., Gorgen K., Beyer M., Hoffmann L. 2012. Ensemble based analysis of regional climate change effects on the cabbage stem weevil (Ceutorhynchus pallidactylus (Mrsh.)) in winter oilseed rape (Brassica napus L.). The Journal of Agricultural Science, 150 (2): 191-202. https://doi.org/10.1017/S0021859611000529

14. Kaiser C., Jensen K.-M. V., Nauen R., Kristensen M. 2018. Susceptibility of Danish pollen beetle populations against lambda-cyhalothrin and thiacloprid. Journal of Pest Science, 91: 447-458. https://doi.org/10.1007/s10340-017-0856-x

15. Kliot A., Ghanim M. 2012. Fitness costs associated with insecticide resistance. Pest Management Science, 68: 1431-1437. https://doi.org/10.1002/ps.3395

16. Krause U., Koopmann B., Ulber B. 2006. Impact of rape stem weevil, Ceutorhynchus napi, on the early stem infection of oilseed rape by Phoma lingam. IOBC/WPRC Bulletin, 29: 323-328.

17. Kudsk P. 2010. NORBARAG (NORdic Baltic Resistance Action Group) - a new resistance action group covering Denmark, Estonia, Finland, Latvia, Lithuania, Norway and Sweden. Outlooks on Pest Management, 21: 223-224. https://doi.org/10.1564/21 oct06
18. Moores G. D., Wegorek P., Zamojska J., Field L., Philippou D. 2011. The effect of a piperonyl butoxide/taufluvalinate mixture on pollen beetle (Meligethes aeneus) and honey bees (Apis mellifera). Pest Management Science, 68: 795-800. https://doi.org/10.1002/ps.2328

19. Mozes-Koch R., Slabezki Y., Efrat H., Kalev H., Kamer Y., Yakobson B. A., Dag A. 2000. First detection in Israel of fluvalinate resistance in the varroa mite using bioassay and biochemical methods. Experimental and Applied Acarology, 24: 35-43. https://doi.org/10.1023/A:1006379114942

20. Nauen R., Zimmer C. T., Andrews M., Slater R., Bass C., Ekbom B., Gustafsson G., Hansen L. M., Kristensen M., Zebitz C. P. W., Williamson M. S. 2012. Target-site resistance to pyrethroids in European populations of pollen beetle, Meligethes aeneus F. Pesticide Biochemistry and Physiology, 103: 173-180. https://doi.org/10.1016/j.pestbp.2012.04.012

21. Philippou D., Field L. M., Wegorek P., Zamojska J., Andrews M.C., Slater R., Moores G. D. 2011. Characterising metabolic resistance in pyrethroids-insensitive pollen beetle (Meligethes aeneus F.) from Poland and Switzerland. Pest Management Science, 67: 239-243. https://doi.org/10.1002/ps.2061

22. Rubil N., Seidenglanz M., Hrudová E., Táncik J., Ruseňáková M. 2018. Description of the situation regarding pollen beetle resistance to insecticides in the Czech Republic and Slovakia. IOBC-WPRS Bulletin, 36: 78-88.

23. Sanchez-Bayo F., Goka K. 2014. Pesticide residues and bees - a risk assessment. PLoS ONE, 9 (4): e94482. https://doi.org/10.1371/journal.pone.0094482

24. Seidenglanz M., Poslušná J., Rotrekl J., Kolařík P., Hrudová E., Tóth P., Havel J., Bernardová M., Spitzer T. 2015 (a). Changes in Meligethes aeneus (Coleoptera: Nitidulidae) susceptibility to lambda-cyhalothrin in the Czech Republic between 2009 and 2011. Plant Protection Science, 51: 24-44. https://doi.org/10.17221/34/2014-PPS

25. Seidenglanz M., Poslušná J., Rotrekl J., Kolařík P., Hrudová E., Tóth P., Havel J., Bernardová M. 2015 (b). Meligethes aeneus (Coleoptera: Nitidulidae) resistance to lambda-cyhalothrin in the Czech Republic in 2012 and 2013. Plant Protection Science, 51 (2): 94-107. https://doi.org/10.17221/40/2014-PPS

26. Seidenglanz M., Poslušná J., Rotrekl J., Kolařík P., Hrudová E., Tóth P., Havel J., Táncik J. 2017. Negative correlations between the susceptibilities of Czech and Slovak pollen beetle populations to lambda-cyhalothrin and chlorpyrifos-ethyl in 2014 and 2015. Plant Protection Science, 53 (2): 108-117. https://doi.org/10.17221/187/2015-PPS

27. Seidenglanz M., Šafář J., Rubil N., Ruseňáková M., Roskóová V. 2018. Does the assessment of eggs in Ceutorhynchus pallidactylus and C. napi ovaries in spring make possible a date for one common spray treatment effective against the weevils and even pollen beetles? IOBC-WPRS Bulletin, 136: 114-125.

28. Slater R., Ellis S., Genay J. P., Heimbach U., Huart G., Sarazin M., Longhurst C., Müller A., Nauen R., Rison J. L., Robin F. 2011. Pyrethroid resistance monitoring in European populations of pollen beetle (Meligethes spp.): a coordinated approach through the Insecticide Resistance Action Committee (IRAC). Pest Management Science, 67: 633-638. https://doi.org/10.1002/ps.2101

29. Stará J., Kocourek F. 2018. Seven-year monitoring of pyrethroid resistance in the pollen beetle (Brassicogethes aeneus F.) during implementation of insect resistance management. Pest Management Science, 74: 200-209. https://doi.org/10.1002/ps.4695

30. Šmatas R., Makūnas V., Brazauskienė I., Petraitienė E. 2012. Sensitivity of pollen beetle (Meligethes aeneus F.) to insecticides with different modes of action and their efficacy in the field conditions. Zemdirbyste-Agriculture, 99 (2): 197-202. 
31. Thieme T., Drbal U., Gloyna K., Hoffmann U. 2008. Different methods of monitoring susceptibility of oilseed rape beetles to insecticides. EPPO Bulletin, 38: 114-117. https://doi.org/10.1111/j.1365-2338.2008.01193.x

32. Tiilikainen T. M., Hokkanen H. M. T. 2008. Pyrethroid resistance in Finnish pollen beetle (Meligethes aeneus) populations - is it around the corner? EPPO Bulletin, 38: 99-103. https://doi.org/10.1111/j.1365-2338.2008.01190.x

33. Tsigouri A. D., Menkissoglu-Spiroudi U., Thrasyvoulou A., Diamantidis G. 2004. Fluvalinate residues in honey and beeswax after different colony treatments. Bulletin of Environmental Contamination and Toxicology, 72: 975-982. https://doi.org/10.1007/s00128-004-0339-7

34. Wegorek P., Mrówczyński M., Zamojska J. 2009. Resistance of pollen beetle (Meligethes aeneus F.) to selected active substances of insecticides in Poland. Journal of Plant Protection Research, 49 (1): 119-127.

https://doi.org/10.2478/v10045-009-0016-2
35. Zimmer C. T., Nauen R. 2011 (a). Pyrethroid resistance and thiacloprid baseline susceptibility of European populations of Meligethes aeneus (Coleoptera: Nitidulidae) collected in winter oilseed rape. Pest Management Science, 67: 599-608. https://doi.org/10.1002/ps.2137

36. Zimmer C. T., Nauen R. 2011 (b). Cytochrome P450 mediated pyrethroid resistance in European populations of Meligethes aeneus (Coleoptera: Nitidulidae). Pesticide Biochemistry and Physiology, 100: 264-272. https://doi.org/10.1016/j.pestbp.2011.04.011

37. Zimmer C. T., Bass C., Williamson M. S., Kaussmann M., Wölfel K., Gutbrod O., Nauen R. 2014. Molecular and functional characterization of CYP6BQ23, a cytochrome P450 conferring resistance to pyrethroids in European populations of pollen beetle, Meligethes aeneus. Insect Biochemistry and Molecular Biology, 45: 18-29. https://doi.org/10.1016/j.ibmb.2013.11.008

ISSN 1392-3196 / e-ISSN 2335-8947

Zemdirbyste-Agriculture, vol. 107, No. 4 (2020), p. 359-366

DOI 10.13080/z-a.2020.107.046

\title{
Rapsinių žiedinukų populiacijų atsparumas lambda- cihalotrinui ir tau-fluvalinatui Čekijoje ir Slovakijoje
}

\author{
M. Seidenglanz ${ }^{1}$, R. Bajerová ${ }^{1}$, P. Kolařík ${ }^{2}$, E. Hrudová 3 , J. Havel ${ }^{4}$, J. Táncik ${ }^{5}$, \\ M. Ruseňáková ${ }^{1}$, P. Bokor ${ }^{6}$, F. Kocourek ${ }^{7}, J$. Stará7 , L. Víchová ${ }^{8}$, J. Šafár ${ }^{1}$ \\ ${ }^{1} \mathrm{AB}$ „Agritec augalų tyrimai“ Augalų apsaugos skyrius, Čekijos Respublika \\ ${ }^{3}$ Mendel universiteto Brno Agronomijos fakultetas, Čekijos Respublika \\ ${ }^{4} \mathrm{AB}$ „OSEVA plètra ir tyrimai“, Čekijos Respublika \\ ${ }^{5}$ ECOPHYTA, Slovakija \\ ${ }^{6}$ Slovakijos žemès ūkio universiteto Nitroje Agrobiologijos ir maisto išteklių fakultetas \\ ${ }^{7}$ Augalų tyrimų instituto Integruotos kenkèjų kontrolès skyrius, Čekijos Respublika \\ ${ }^{8}$ Centrinio žemès ūkio priežiūros ir tyrimų instituto (ÚKZÚZ) Diagnostikos laboratorijų skyrius, \\ Čekijos Respublika
}

\section{Santrauka}

Rapsinių žiedinukų (Brassicogethes aeneus F.) 251 populiacijos, surinktos Čekijos Respublikoje ir Slovakijoje, atsparumas lambda-cihalotrinui ir tau-fluvalinatui, naudojant Insekticidų atsparumo veiksmų komiteto (IRAC) jautrumo testo 11 metodo 03 versiją (vial test) buvo tirtas ketverius (2015-2018) metus. Tyrimo rezultatai patvirtino abiejų šalių žiedinukų populiacijų aukštą atsparumo lambda-cihalotrinui lygị. Atsparumas tau-fluvalinatui buvo mažesnis, tačiau dèl gana didelio atsparių populiacijų kiekio daugelyje vietovių abiejose šalyse kenkẻjai šiam insekticidui tapo atsparūs. Letalinès dozès (LC) verčių $\left(\mathrm{LC}_{50}\right.$ ir bent iš dalies $\left.\mathrm{LC}_{90}\right)$ koreliacinès analizès rezultatai parodè vidutinị kryžminio atsparumo abiem veikliosioms medžiagoms lygi Cekijos populiacijose. Slovakijos populiacijose teigiama koreliacija tarp $\mathrm{LC}_{50}$ verčių buvo reikšminga tik 2018 metais $(r=0,66, p<0,001)$. Nepaisant šio tyrimo metu nustatyto tam tikro koreliacijos analizès rezultatų varijavimo, gauti duomenys parodè dar vieną galimą žiedinukų jautrumo piretroidams sumažèjimą, jeigu jų kontrolè lauko sąlygomis buvo vykdyta naudojant tau-fluvalinatą.

Reikšminiai žodžiai: Brassicogethes aeneus, I klasès piretroidai, II klasės piretroidai, suaugusių žiedinukų buteliukų testas, atsparumas insekticidams, žieminiai rapsai. 